\title{
THE RESISTANCE TO FLUCONAZOLE IN PATIENTS WITH ESOPHAGEAL CANDIDIASIS
}

\author{
Ana Botler WILHEIM1', Demócrito de Barros MIRANDA-FILH01, \\ Rodrigo Albuquerque NOGUEIRA², Rossana Sette de Melo RÊGO², \\ Kedma de Magalhães LIMA ${ }^{4}$ and Leila Maria Moreira Beltrão PEREIRA ${ }^{1}$
}

\begin{abstract}
Context - Esophageal candidiasis is often observed in patients with risk factors for its development and fluconazole is the therapeutic choice for the treatment of this disease. Objectives - To determine its frequency, by performing upper digestive endoscopy; to determine Candida species involved in its pathogenesis and verify their distribution according with the predisposing factors and to determine susceptibility to fluconazole in the samples. Methods - From March 2006 to April 2007, all patients submitted to esophagogastroduodenoscopy at the Digestive Endoscopy Unit in the Oswaldo Cruz University Hospital, Recife, PE, Brazil, were eligible for the study. Samples were collected from patients who presented lesions consistent with esophageal candidiasis in order to identify Candida species and verify their susceptibility to fluconazole. The predisposing factors for the occurrence of esophageal candidiasis were described. Results - Of 2,672 patients referred to upper endoscopy at the Digestive Endoscopy Unit, 40 (1.5\%) had endoscopic findings compatible with esophageal candidiasis. The average age was 49.1 years. Twenty one patients (52.5\%) were less than 50 years old, of which $82.6 \%$ were infected with HIV. Most of them (52.5\%) were males and $65.0 \%$ were inpatients. Diseases were identified in $90 \%$ of the patients and $21(52.5 \%)$ were HIV positive. Concerning endoscopic findings, severe forms of esophagitis were found in $50 \%$ of the patients with CD4 count $<200$. Non-albicans Candida species were isolated in $22.7 \%$ of HIV positive and in $45 \%$ HIV negative patients. A total of $6(14.28 \%)$ samples were resistant to fluconazole, while 2 (4.76\%) samples had dose depending susceptibility to this drug. Conclusions - Esophageal candidiasis prevalence was low, although within the results described by other authors. Male and inpatients were the most affected. The species isolated varied according to the characteristics of each group studied. Both, resistance and dose-depending susceptibility to fluconazole were considered high.

HEADINGS - Candidiasis. Esophageal diseases. Fluconazole. Drug resistance, fungal.
\end{abstract}

\section{INTRODUCTION}

In 1839, a fungus was first described as the etiological factor of esophageal candidiasis (EC) in a patient who died due to typhoid fever. At that time no association was acknowledged between immunodepression and $\mathrm{EC}^{(13)}$. Nowadays, fungal esophagitis is well known to occur in immunocompromised hosts. Well-estabilished predisposing factors are AIDS, hepatic failure, neoplasms and diabetes mellitus ${ }^{(2,5,21,22,29)}$. EC has also been described in immunocompetent patients who underwent upper endoscopy ${ }^{(1,6,12)}$. Prolonged use of antibiotics, corticosteroids and immunosuppressors are related as risk factors for its development $t^{(5,6,11,16,21,22,29)}$.

With the improvement of flexible endoscopes and the increase in their use, from the 70s on, samples obtained under direct vision of the digestive tract became possible ${ }^{(17)}$ and thus, the diagnosis of EC was enhanced ${ }^{(5,16,21,22,29)}$.

Since 1990, the introduction of a new generation of oral triazole antifungal agents marked an important advance in the management of candidal infections. Fluconazole is the drug of choice for the treatment of $\mathrm{EC}^{(3,7,26,30)}$. It is generally safe, well tolerated and has been shown to produce a rapid clinical response. Moreover, fluconazole can be absorbed at any gastric $\mathrm{pH}$ and has minimal effects on steroid synthesis, which did not occur with the agents previously used ${ }^{(9)}$. However, certain Candida species are intrinsically (e.g., Candida krusei in 100\%) or intermediately resistant (e.g. C. glabrata in $60 \%$ ) to fluconazole in vitro ${ }^{(25,34)}$

In Brazil, there are no studies describing the frequency of Candida species which cause EC. The knowledge of associated predisposing factors to esophageal infection, as well as Candida species and their susceptibility to fluconazole may facilitate the therapeutic guidance, especially in patients prone to relapse.

\section{METHODS}

\section{Patient selection}

All patients referred to upper gastrointestinal endoscopy at the Digestive Endoscopy Unit in "Oswaldo Cruz" University Hospital, Recife, PE, Brazil, between March 2006 and April 2007 were eligible for the study. ${ }^{1}$ Department of Internal Medicine, School of Medical Sciences, University of Pernambuco; ${ }^{2}$ School of Medical Sciences, University of Pernambuco; ${ }^{3}$ Microbiology
Department, NKB Diagnosis of Pernambuco; ${ }^{4}$ Department of Tropical Disease, Federal University of Pernambuco, Recife, PE, Brazil.

Correspondence: Dr. Ana Botler Wilheim - Rua Manuel Bernardes, 134 - apt.1501 - Madalena - 50710-350 - Recife, PE, BRASIL. E-mail: abotler@terra.com.br 
Recurrence was defined as a new episode of EC 1 month after remission. When this happened, the patient was considered as another case.

Fragments of whitish plaques adhered to the mucosa, compatible with Candida esophagitis, were collected with a biopsy forceps and sent for culture and species identification, without proceeding histopathological analysis.

Informed consent was obtained from each patient and approval for the study protocol was granted by the Ethics Committee of the Institution. Inclusion criteria consisted of diagnosis of EC and signature of informed consent.

\section{Sample processing}

When collected, samples were placed in Agar Sabouraud plates, a fungus selective medium, with cloranfenicol $(50 \mathrm{mg} / \mathrm{L})$, in order to prevent bacterial growth. After growth, colonies were again purified in distilled water and antibiotics and sowed in simple Agar Sabouraud plates. Hence, it was possible to isolate fungus specimens and proceed the biochemical tests for species identification.

The next step consisted in placing the samples in a chromogenic culture media which allowed instant pre-identification by eye of colonies of Candida $\left(\mathrm{CHROMagar}^{\circledR}\right)$. Through this presumptive technique, C. albicans colonies showed a greenish pattern, whilst other species presented distinct colours. Microcultive with corn meal Agar was further used to identify Candida species, refining previous tests obtained with chromogenic media ${ }^{(18)}$.

Figure 1 describes Fluconazole susceptibility standards set by Disk-diffusion method (M44/NCCLS M27-A) for Candida spp used in this study.

\begin{tabular}{|cccc|}
\hline Drug & Sensitive & Dose depending susceptibility (DDS) & Resistant \\
\hline Fluconazole & $\geq 19 \mathrm{~mm}$ & $15-18 \mathrm{~mm}$ & $<15 \mathrm{~mm}$ \\
\hline
\end{tabular}

FIGURE 1. Pattern of response to fluconazole

Endoscopic procedures were performed with Olympus (Exera 160) videoendoscopes and Medglobe ${ }^{\circledR}$ biopsy forceps, sterilized according to Brazilian Society of Digestive Endoscopy (SOBED) recommendations.

\section{Study design and statistical methods}

Adescriptive, exploratory study - a series of cases - was conducted. Data were obtained prospectively by filling a specific formulary for each patient included in the research. The formulary was filled by interviewing the patient after endoscopy was performed. Some informations were acquired by reviewing medical records.

Data were typed in double entrance using EPI-INFO 6.0, which were then compared to avoid typing mistakes. The analysis was done by identifying the frequencies of variables. To demonstrate absolute values and their correlated proportions, tables were used.

\section{RESULTS}

Among 2,672 patients referred for endoscopy at "Oswaldo Cruz" Hospital, 40 (1.5\%) had esophageal whitish plaques adhered to the mucosa, compatible with EC, according to Wilcox's endoscopic grading ${ }^{(33)}$. Mean age was 49.1 years, ranging from 31 to 66 years. Most of them (52.5\%) were males and $65 \%$ were inpatients.

Predominant symptoms were dysphagia (47.5\%), nausea and/or vomiting $(32.5 \%)$, heartburn $(32.5 \%)$, odynophagia $(22.5 \%)$ and abdominal pain $(20 \%)$. Five $(12.5 \%)$ patients were asymptomatic. Of those, three had diabetes, one had neoplasm and none was HIV positive.

Table 1 describes cases according to age, predisposing factors, previous fluconazole use, CD4 count, grading of endoscopic esophagitis, isolated species of Candida and fluconazole susceptibility testing for each sample.

Associated diseases were identified in $36(90 \%)$ patients: HIV in $21(52.5 \%)$, diabetes mellitus in $6(15 \%)$, chronic liver disease in $3(7.5 \%)$, neoplasms in $2(5 \%)$ and $4(10 \%)$ had risk factors for EC, such as steroid use.

Most patients under 50 years of age $(82.6 \%)$ were HIV positive. From that amount, $11(52.4 \%)$ were in use of anti-retroviral therapy. Recent CD4 counting was known in $14(66.7 \%)$ and its average was $157.7\left( \pm 132.14 / \mathrm{mm}^{3}\right)$. Eight patients $(57.2 \%)$ had CD4 count below 200 cells $/ \mathrm{mm}^{3}$, all of them in rescue scheme. Half of these patients were knowingly dead by the end of this study. Most severe presentations of esophagitis were in patients with greater immunologic compromise (Table 2).

Eighteen (45\%) patients were taking antibiotics. Most of them were HIV positive $(94.4 \%)$, and of this total $81 \%$ were in anti-retroviral therapy. Eight (20\%) out of the HIV positive had previously used fluconazole.

Two cases of species association were detected: $C$. albicans with $C$. krusei and $C$. glabrata with $C$. tropicalis. The last case was a recurrence of $\mathrm{EC}$, when the previous isolated agent was C. albicans.

Fluconazole resistance was observed in six (14.28\%) samples, while dose-depending susceptibility occurred in two $(4.76 \%)$. When two species were associated, one of them was resistant to this drug. Three $(50 \%)$ out of the patients resistant to fluconazole had used this drug in the past, whereas no previous use of any kind of azoles was reported by the patients with dose-depending susceptibility.

\section{DISCUSSION}

A worldwide survey during the 90s showed that among all patients submitted to upper endoscopy EC frequency ranged from $1 \%$ to $8 \%{ }^{(8)}$. In 2003 , UNDERWOOD et al. ${ }^{(29)}$ found that from the total of patients submitted to endoscopy during 1 year, $18(0.8 \%)$ had EC. Likewise, in Argentina in $2005^{(21)}, 34(2.6 \%)$ of such patients were found to have EC.

"Oswaldo Cruz" University Hospital is a reference unit for infectious diseases, oncology, hepatopathy, internal medicine and pneumology. This is probably the reason why a large number of EC patients were referred to endoscopy. In addition, considering that inpatients accounted for $65 \%$ of the subjects in this study, there was also a greater possibility that immunocompromised patients under antibiotics or steroid use were submitted to this exam. Moreover, previous knowledge of this study by the 
TABLE 1. Case description according to age, predisposing factors, previous use of fluconazole, CD4 count, esophagitis degree, isolated species in culture and fluconazole susceptibility testing for each sample

\begin{tabular}{|c|c|c|c|c|c|c|c|}
\hline Sample & $\begin{array}{c}\text { Age } \\
\text { (years) }\end{array}$ & $\begin{array}{c}\text { Predisposing } \\
\text { factors }\end{array}$ & $\mathrm{CD} 4$ count & $\begin{array}{c}\text { Wilcox grading } \\
\text { esophagitis }\end{array}$ & Isolated species & $\begin{array}{l}\text { Response to } \\
\text { fluconazole }\end{array}$ & Fluconazole use \\
\hline 1 & 33 & HIV, CS, ATB & - & I & C. tropicalis & $\mathrm{R}$ & + \\
\hline 2 & 23 & HIV, ATB & 320 & II & C. albicans & $\mathrm{s}$ & - \\
\hline 3 & 79 & DM & - & I & C. tropicalis & $\mathrm{S}$ & - \\
\hline 4 & 32 & HIV, ATB & 34 & II & C. albicans & $\mathrm{s}$ & - \\
\hline 5 & 68 & DM & - & I & C. albicans & S & - \\
\hline 6 & 42 & DM, CS & - & I & C. albicans & S & - \\
\hline 7 & 21 & - & - & II & C. tropicalis & s & - \\
\hline 8 & 52 & CLD , CS & - & II & C. tropicalis & DDS & - \\
\hline 9 & 38 & HIV & 93 & I & C. albicans & S & - \\
\hline 10 & 41 & HIV, АTB & 282 & II & C. albicans & S & - \\
\hline 11 & 30 & HIV, ATB & 43 & IV & C. albicans & S & - \\
\hline 12 & 50 & HIV, ATB & 249 & I & C. albicans & DDS & - \\
\hline 13 & 84 & - & - & I & C. tropicalis & S & - \\
\hline 14 & 34 & HIV, ATB & - & I & C. albicans & S & + \\
\hline 15 & 41 & HIV, ATB & 282 & III & $\begin{array}{l}\text { C. tropicalis } \\
\text { C. glabrata }\end{array}$ & $\begin{array}{l}\mathrm{S} \\
\mathrm{R}\end{array}$ & + \\
\hline 16 & 24 & HIV, ATB & 10 & II & C. albicans & S & + \\
\hline 17 & 64 & - & - & I & C. tropicalis & S & - \\
\hline 18 & 39 & HIV, АTB & 91 & III & C. tropicalis & $\mathrm{R}$ & + \\
\hline 19 & - & HIV & - & I & C. albicans & S & - \\
\hline 20 & 43 & CS & - & III & C. albicans & S & - \\
\hline 21 & 42 & HIV, АTB & - & I & C. glabrata & S & - \\
\hline 22 & 60 & DM & - & I & C. tropicalis & S & - \\
\hline 23 & 43 & HIV, ATB & 17 & III & C. albicans & S & - \\
\hline 24 & 32 & HIV, АTB & - & I & C. albicans & S & - \\
\hline 25 & 57 & HIV & - & III & C. albicans & S & - \\
\hline 26 & 82 & DM & - & I & C. glabrata & $\mathrm{R}$ & - \\
\hline 27 & 77 & CLD & - & I & $\begin{array}{l}\text { C. krusei } \\
\text { C. albicans }\end{array}$ & $\begin{array}{l}\mathrm{R} \\
\mathrm{S}\end{array}$ & - \\
\hline 28 & 45 & HIV & - & IV & C. albicans & S & - \\
\hline 29 & 64 & Neoplasia & - & II & C. albicans & S & - \\
\hline 30 & 25 & HIV, ATB & 213 & I & C. albicans & S & + \\
\hline 31 & 73 & CLD & - & I & C. albicans & S & - \\
\hline 32 & 61 & CS & - & I & C. albicans & S & - \\
\hline 33 & 35 & HIV, АTB & 161 & II & C. albicans & $\mathrm{R}$ & + \\
\hline 34 & 70 & CS & - & I & C. albicans & S & - \\
\hline 35 & 55 & $\mathrm{DM}$ & - & I & C. albicans & S & - \\
\hline 36 & 54 & Neoplasia & - & II & C. albicans & s & - \\
\hline 37 & 41 & HIV, АTB & 13 & III & C. albicans & $\mathrm{s}$ & + \\
\hline 38 & 42 & HIV, АTB & 400 & II & C.parapsilosis & S & - \\
\hline 39 & 44 & CS, ATB & - & I & C. albicans & S & - \\
\hline 40 & 76 & - & - & I & C. albicans & $\mathrm{s}$ & - \\
\hline
\end{tabular}

HIV = human immunodeficiency syndrome virus infection; $D M=$ diabetes mellitus; $A T B=$ antibiotics use; $C E=$ corticosteroids use; $C L D=$ chronic liver disease; $S=$ susceptible; $R=$ resistant; $D D S=$ dose-depending susceptibility

TABLE 2. Patients distribution according to endoscopic findings, infection by HIV and CD4 count

\begin{tabular}{|c|c|c|c|c|c|c|c|c|c|c|}
\hline \multirow{3}{*}{ EC grading } & \multicolumn{6}{|c|}{ HIV positive } & \multirow{2}{*}{\multicolumn{2}{|c|}{$\begin{array}{c}\text { HIV } \\
\text { negative }\end{array}$}} & \multirow{2}{*}{\multicolumn{2}{|c|}{ Total }} \\
\hline & \multicolumn{2}{|c|}{$\mathrm{CD} 4<200$} & \multicolumn{2}{|c|}{$\mathrm{CD} 4 \geq 200$} & \multicolumn{2}{|c|}{$\begin{array}{c}\text { Unkown } \\
\text { CD4 }\end{array}$} & & & & \\
\hline & $\mathrm{n}$ & $\%$ & $\mathrm{n}$ & $\%$ & $\mathrm{n}$ & $\%$ & $\mathrm{n}$ & $\%$ & $\mathrm{n}$ & $\%$ \\
\hline Wilcox 1-2 & 4 & 50 & 5 & 83.3 & 5 & 71.4 & 18 & 94.7 & 32 & 80 \\
\hline Wilcox 3-4 & 4 & 50 & 1 & 16.7 & 2 & 28.6 & 1 & 5.3 & 8 & 20 \\
\hline TOTAL & 8 & 20 & 6 & 15 & 7 & 17.5 & 19 & 47.5 & 40 & 100 \\
\hline
\end{tabular}

greater intensity of endoscopic findings. WERNECK-SILVA and PRADO ${ }^{(32)}$, in 2007, however, did not support this observation. On the other hand, MOCROFT et al. ${ }^{(19)}$, in 2005, found that HIV medical staff might have contributed to an increase in referrals for acknowledgement of digestive complaints, especially those of patients refractory to clinical treatment. The frequency of $1.5 \%$ of EC found in this study was relatively low, although within the expected variation mentioned in most recent publications.

AIDS patients represented over half the cases. Most severe forms of EC were more frequent in patients with greater immunologic compromise, expressed by CD 4 count below 200 cells $/ \mathrm{mm}^{3}$. This fact may suggest that the more severe are the endoscopic findings, the more intensive is the magnitude of immunodepression.

However, most HIV patients with CD4 count below 200 were also in use of antibiotics, which might have contributed to a 
positive patients had a decline in EC frequency once immunity was restored by use of anti-retroviral drugs. Comparative studies with appropriate samples are needed to investigate the accuracy of this observation.

The endoscopic finding of EC in patients without digestive complaints must be valued. In this study, among the five asymptomatic patients, three had diabetes and one had neoplasm. Glycemic control in diabetic patients may help or even resolve esophageal infection ${ }^{(29)}$. On bearers of neoplasm, EC might represent a progressive immunity decline. A case-control study settled in the United Kingdom found out that $70 \%$ of EC patients aged over 65 were submitted to endoscopy due to weight loss and anemia. The authors concluded this to be a limited survival marker, since elders tend to naturally loose their innate immunity $^{(31)}$. Once EC is found in patients with possibilities of recovering their immunity conditions, this may lead to indicate the need for correction of the predisposing factors. However, in patients whose immunity might not be restored, EC could represent a poor prognosis marker. This might also be valid for HIV positive patients with inadequate response to potent antiretroviral therapy. Half of the patients with CD4 count below 200 from our series were knowingly dead by the end of this study. This outcome also matches that of a study done by MACROFT et al. ${ }^{(19)}$, which indicates short life expectancy for patients with EC and low levels of CD4.

REDAH et al. ${ }^{(24)}$ reported a high endoscopic yield for the endoscopic diagnosis of $C$. albicans, detecting sensitivity, specificity, positive and negative predictive values of $100 \%$, $83 \%, 88 \%$ and $100 \%$, respectively. They emphasize, however, the importance of identifying species for better characterization of the diseases' behavior. LYMAN et al. ${ }^{(15)}$ also studied the importance of identifying Candida species involved, since the in vivo response to fluconazole is related to its in vitro response as well as to its mucosa adhesion ability.

Eight (20\%) samples in this study would have been improperly treated if the endoscopic aspect was the only one considered, that is, samples that showed to be resistant or to have dose-depending susceptibility to fluconazole.

Table 2 shows patients' distribution according to endocopic findings, infection by HIV and CD4 count.

Candida albicans frequency amongst HIV positive patients in this study $(77.3 \%)$ is coincident with that found in the literature, which describes $C$. albicans as the most frequently identified agent in esophageal disease, varying from $42 \%$ to $79 \%$ of the infected patients ${ }^{(20)}$. Non-albicans Candida species were found in $22.7 \%$ HIV-positive and in $45 \%$ uninfected patients. Hence, the last group hosted almost twice as much the amount of nonalbicans species as the first group. There was no statistically significant difference between them, probably due to the reduced size of the sample.

The pattern of species association described in this study may have clinical implications due to empirical treatment with fluconazole. The latter may have eradicated the species susceptible to the drug, namely, albicans and tropicalis, thus tending to perpetrate esophageal infection through selective growth of krusei and glabrata species, which are both resistant, in vitro, to fluconazole.

The drug of choice for EC treatment is fluconazole ${ }^{(3,7,23,26,30)}$. Studies have demonstrated that fluconazole prophylaxis reduces the chances of both colonization and invasive fungi infections in high risk patients ${ }^{(4)}$. However, randomized clinical assay evidences suggest that its use increases the risk for colonization by resistant, dose-depending susceptible ${ }^{(4,27,30)}$ and non-albicans species $^{(4)}$.

In this series of cases, fluconazole resistance occurred in six (14\%) samples and dose-depending susceptibility in two $(4 \%)$. Half the patients who presented drug resistance related previous fluconazole use, which is considered the most important factor for this outcome ${ }^{(4,14)}$. Most were HIV positive under 50 years of age, and CD4 count $<200$ was found in $34 \%$, which also might sign a possible indicator for resistance ${ }^{(14)}$.

Two $(66.7 \%)$ out of three patients who had previously used fluconazole in this study had non-albicans species. An increase in colonization by non-albicans species was demonstrated by BRION et al. ${ }^{(4)}$ in a systematic review of randomized clinical assays.

Resistance to fluconazole found by GOLDMAN et al. ${ }^{(10)}$ was $4.1 \%$ in patients on continuous and $4.3 \%$ on sporadic fluconazole intake. All patients had a CD4 count $<150$ and both groups showed no difference in overall survival rates. Hence, fluconazole resistance in this study represents almost three and a half times the rates found in the literature review.

Despite the high frequency of resistance found, one should not diminish the role of fluconazole in EC treatment. Patients without previous episode of EC or without previous use of fluconazole, immunocompromised or not, will possibly respond well to this drug, since the proper management of existing predisposing factors is provided.

In cases of recurrence of the esophageal infection, species identification and susceptibility testing for fluconazole are indicated. Both measures might indicate distinct approaches to conduct the disease. In case of resistant species, another drug therapy will be needed. Fluconazole, however, remains useful in dose-depending susceptibility, in which case only the dose adjustment will be enough to resolve EC. 
Wilheim AB, Miranda-Filho DB, Nogueira RA, Rêgo RSM, Lima KM, Pereira LMMB. Resistência ao fluconazol em pacientes com candidíase esofágica. Arq Gastroenterol. 2009;46(1): 32-7.

RESUMO - Contexto - A candidíase esofágica é comumente observada em pacientes com fatores de risco para seu desenvolvimento. Objetivos - Determinar a freqüência da candidíase esofágica, por meio da endoscopia digestiva alta; identificar as espécies de Candida envolvidas na patogênese da candidíase esofágica e sua distribuição de acordo com o fator predisponente; determinar a susceptibilidade ao fluconazol nas amostras coletadas. Métodos - De março de 2006 a abril de 2007, os pacientes submetidos a esofagogastroduodenoscopia no Hospital Universitário Oswaldo Cruz, Recife, PE, foram considerados elegíveis para o estudo. Aqueles que apresentaram lesões compatíveis com candidíase esofágica tiveram amostras coletadas para a identificação das espécies de Candida, de sua sensibilidade ao fluconazol e descritos os fatores de risco para a doença. Resultados - Dos 2.672 pacientes encaminhados para endoscopia, 40 ( $1,5 \%$ ) apresentaram achados compatíveis com candidíase esofágica. A média de idade foi de 49,1 anos. Vinte e um pacientes (52,5\%) tinham menos que 50 anos, dos quais $82,6 \%$ eram infectados pelo HIV. A maioria (52,5\%) era homens e $65,0 \%$ encontravam-se internados. Fatores predisponentes foram identificados em $90 \%$ da amostra, sendo que 21 (52,5\%) eram HIV positivos. As formas mais graves de esofagite foram encontradas em $50 \%$ dos pacientes com CD $4<200$. Espécies de Candida não-albicans foram detectadas em 22,7\% dos pacientes HIV positivos e em $45 \%$ dos pacientes não infectados. A resistência ao fluconazol foi observada em seis amostras (14,28\%) e a sensibilidade dose-dependente em duas (4,76\%). Conclusão - A prevalência de candidíase esofágica foi baixa, embora dentro de variação esperada. Pacientes homens e que estavam internados foram os mais acometidos. Houve variação nas espécies encontradas, de acordo com as características dos grupos estudados. Tanto a resistência ao fluconazol como a sensibilidade dose-dependente foram consideradas altas.

DESCRITORES - Candidíase. Esofagiopatias. Fluconazol. Farmacorresistência fúngica.

\section{REFERENCES}

1. Aleman C, Alegre J, Surinach JM, Jufresa J, Falco V, Fernandez De Sevilla T. Esophageal candidiasis in patients without cellular immunity changes. Report of 7 cases. Rev Clin Esp. 1996;196:375-7.

2. Baher PH, McDonald GB. Esophageal infections: risk factors, presentation, diagnosis and treatment. Gastroenterology. 1994;106:509-32.

3. Böhme A, Ruhnke M, Buchheidt D, Karthaus M, Einsele H, Guth S, Heussel G, Heussel CP, Junghanss C, Kern WK, Kubin T, Masschemeyser G, Sezer O, Silling G, Sudhoff T, Szelenyi Dagger H, Ullmann AJ. Treatment of fungal infections in hematology and oncology-guidelines of the infectious disease working party (AGIOF) of the German Society of Hematology and Oncology (DGOH). Ann Hematol. 2003;82(suppl 2):133-40.

4. Brion LP, Uko SE, Goldman DL. Risk of resistance associated with fluconazole prophylaxis: systematic review. J Infect. 2007;54:521-9.

5. Chocarro Martinez A, Galindo Tobal F, Ruiz-Irastorza G, Gonzáles López A, Alvarez Navia F, Ochoa Sangrador C, Martin Aribas MI. Risk factors for esophageal candidiasis. Eur J Clin Microbiol Infect Dis. 2000;19:96-100.

6. Cortés C, Oksenberg D, Afani A, Defilippi C, Madrid AM. Clinical and immunological study of 10 immunocompetent patients with esophageal candidiasis. Rev Med Chil. 2004;132:1389-94.

7. Darouiche RO. Oropharyngeal and esophageal candidiasis in immunocompromised patients: treatment issues. Clin Infect Dis. 1998;26:259-74.

8. Fraimow HS, Klein RS. Treatment of esophageal infections in the immunocompromised host. In: Wolf MM, editor. Therapy of digestive disorders. Philadelphia, PA: WB Saunders; 2000. p.767-84

9. Goa KL, Barradell LB. Fluconazole. An update of its pharmacodynamic and pharmacokinetic properties and therapeutic use in major superficial and systemic mycosis in immunocompromised patients. Drugs. 1995;50:658-90.

10. Goldman M, Cloud GA, Wade KD, Reboli AC, Fichtembaum CJ, Hafner R, Sobel JD, Powderly WG, Patterson TF, Wheat LJ, Stein DK, Dismukes WE, Filler SG. A randomized study of the use of fluconazol in contiuous versus episodic therapy in patients with advanced HIV infection and a history of oropharyngeal candidiasis: AIDS Clinical Trials Group Study 323/Mycosis Study Group Study 40. Clin Infect Dis. 2005;41:1481-2.

11. Kanda N, Yasuba H, Takahashi T, Mizuhara Y, Yamazaki S, Imada Y, Izumi Y, Kobayashi Y, Yamashita K, Kita H, Tamada T, Chiba T. Prevalence of esophageal candidiasis among patients treated with inhaled fluticasone propionate. Am J Gastroenterol. 2003;98:2146-8.

12. Kasapidis P, Kokkinou E. Experience with Candida esophagitis in young patients without predisposing factors. Gut. 1997;41:509.
13. Knoke M, Bernhardt $H$. The first description of an oesophageal candidosis by Bernhardt Von Langenbeck in 1839. Mycosis. 2006;49:283-7.

14. Laing RB, Brettle RP, Leen CL. Clinical predictors of azole resistance, outcome and survival from oesophageal candidiasis in AIDS patients. Int J STD AIDS 1998;9:16-20.

15. Lyman CA, Garrett KF, Peter J, Gonzalez C, Walsh TJ. Increased adherence of fluconazole-resistant isolates of candida species to explanted esophageal mucosa. Eur J Microbiol Infect Dis. 1999;18:213-6.

16. Mathieson R, Dutta SK. Candida esophagitis. Dig Dis Sci. 1983;28:365-70.

17. McCloy RF. Endoscopy. Curr Opin Gastroenterol. 1987;3:967-70.

18. Milan EP, Zaror L. Leveduras: identificação laboratorial. In: Sidrim JJC, Rocha MFG, editores. Micologia médica à luz de autores contemporâneos. Rio de Janeiro: Guanabara Koogan; 2004. p.89-101.

19. Mocroft A, Oancea C, Lunzen J, Vanhems P, Banhegyi D, Chiesi A, Vinogradova E, Maayan S, Phillips A, Lundgreen J. Decline in esophageal candidiasis and use of antimycotics in European patients with HIV. Am J Gastroenterol. 2005;100: 1446-54.

20. Noyer CM, Simon D. Oral and esophageal disorders. Gastroenterol Clin North Am. 1997;26:241-57.

21. Olmos MA, Araya V, Concetti H, Ramalho J, Piskorz E, Pérez H, Cahn P, Kaufman S, Guelfand L. Oesophageal candidiasis: clinical and mycological analysis. Acta Gastroenterol Latinoam. 2005;35:211-8.

22. Ortuño CJA, Tovar MA, Ruiz RJ, García A. Esophageal candidiasis in HIV-negative patients. Rev Esp Enferm Dig. 1997;89:503-10.

23. Pappas PG, Rex JH, Sobel JD, Filler SG, Dismukes WE, Walsh TJ, Edwards JE Guidelines for treatment of candidiasis. Clin Infect Dis. 2004;38:161-89.

24. Redah D, Konustse AY, Agbo K, Dogbey EH, Napo-Koura G, Tchangai-Kao ST, PrinceDavid M, Amedegnato DM, Agbetra A. Is endoscopic diagnosis of Candida albicans esophagitis reliable? Correlations with pathology and mycology. Gastroenterol Clin Biol. 2001;25:161-3.

25. Redding S, Smith J, Farinacci G, Rinaldi M, Fothergill A, Rhine-Chalberg J, Pfaller M. Resistance of Candida albicans to fluconazole during treatment of oropharyngea candidiasis in a patient with AIDS: documentation by in vitro susceptibility testing and DNA subtype analysis. Clin Infect Dis. 1994;18:240-2.

26. Rex JH, Walsh TJ, Sobel JD, Filler SG, Pappas PG, Dismuskes WE, Edwards JE. Practice guidelines for the treatment of candidiasis. Clin Infect Dis. 2000;30: 662-78.

27. Takasawa H, Takahashi Y, Abe M, Osame K, Watanabe S, Hisatake T, Yasuda K, Kaburagi Y, Kajio H, Noda M. An elderly case of type 2 diabetes which developed in association with oral and esophageal candidiasis. Intern Med. 2007;46: 387-90. 
28. Tapia C, Gonzáles P, Pereira A, Perez J, Noriega LM, Palavecino E. Antifungal susceptibility for Candida albicans isolated from AIDS patients with oropharyngeal and esophageal candidiasis: experience with Etest. Rev Med Chil. 2003;131 515-9.

29. Underwood JA, Williams JW, Keate RF. Clinical findings and risk factors for candida esophagitis in outpatients. Dis Esophagus. 2003;16:66.

30. Vazquez JA. Invasive oesophageal candidiasis: current and developing treatment options [review]. Drugs. 2003;63:971-89.

31. Weerasuriya N, Snape J. A study of candida esophagitis in elderly patients attending a district general hospital in UK. Dis Esophagus. 2006;19:189-93.

32. Werneck-Silva AL, Prado IB. The relationship between immunological status and severity of endoscopic lesions in candida esophagitis is not perfect in HIV-Infected patients [abstract]. In: Meeting Abstracts of Digestive Disease Week, 2007, Washington, DC. Gastrointest Endosc. 2007:65[abstract 148].

33. Wilcox CM. A technic to examine the underlying mucosa in patients with AIDS and severe candida esophagitis. Gastrointest Endosc. 1995;42:360-3.

34. Wingard JR, Merz WG, Rinaldi MG, Johnson TR, Karp JE, Saral R. Increase in Candida krusei infection among patients with bone marrow transplantation and neutropenia treated prophylactically with fluconazole. N Engl J Med. 1991;9:1274-7.

Recebido em $7 / 2 / 2008$ Aprovado em 22/12/2008 